\title{
INCIDENCE OF UROSEPSIS IN PATIENTS DIAGNOSED WITH DIABETIC KETOACIDOSIS ADMITTED IN TERTIARY CARE CENTRE
}

\author{
Anbarasu Duraisamy¹, Kumaresan Soorappa Ponnusamy2, Vijayakumar Nagarajan³, Thirunavukkarasu Subrmanian ${ }^{4}$
}

${ }^{1}$ Associate Professor, Department of General Medicine, Government Vellore Medical College, Vellore.

${ }^{2}$ Associate Professor, Department of General Medicine, Government Vellore Medical College, Vellore.

3 Postgraduate, Department of General Medicine, Government Vellore Medical College, Vellore.

${ }^{4}$ Postgraduate, Department of General Medicine, Government Vellore Medical College, Vellore.

\begin{tabular}{l}
\hline ABSTRACT \\
AIM \\
To determine the incidence of urosepsis in patients with diabetic ketoacidosis admitted in Government Vellore Medical College \\
Hospital. To identify the common pathogens causing Urosepsis in Diabetic Ketoacidosis patients in our hospital.
\end{tabular}

METHOD

This cross-sectional study on the incidence of Urosepsis in diabetic ketoacidosis was done in patients admitted with DKA in our Intensive Medical Care Unit from March 2016 to August 2016.

\section{RESULTS}

A total sample of 103 patients admitted with DKA were included in the study. Of the study population, 12 (11.6\%) were type 1 DM and 91 (88.4\%) were type 2 DM. The incidence of urosepsis in DKA in our study is 13.59\%, of which 11 (78.57\%) were females and $3(21.42 \%)$ were males ( $\mathrm{p}<0.05)$. The organisms causing urosepsis were E. coli in 9 patients $(64.28 \%)$, Klebsiella in 2 patients $(14.28 \%)$ and pseudomonas aeruginosa in 1 patient (7.14\%), staphylococcus epidermidis in 1 patient (7.14\%) and candida glabrata in 1 patient $(7.14 \%)$.

\section{CONCLUSION}

The incidence of urosepsis in DKA was $13.59 \%$ with E. coli being the commonest organism isolated.

\section{KEYWORDS}

Diabetic Ketoacidosis, Urosepsis, Diabetes Mellitus.

HOW TO CITE THIS ARTICLE: Duraisamy A, Ponnusamy KS, Nagarajan V, et al. Incidence of urosepsis in patients diagnosed with diabetic ketoacidosis admitted in tertiary care centre. J. Evolution Med. Dent. Sci. 2016;5(73):5367-5369, D0I: $10.14260 /$ jemds/2016/1218

\section{INTRODUCTION}

Diabetic ketoacidosis is one of the common medical emergencies of diabetes mellitus. ${ }^{1}$ Of the various precipitating factors for the development of diabetic ketoacidosis, omission of insulin and infection are the common factors. ${ }^{2}$ Among various infections, respiratory and urinary tract infections are the commonest precipitants of DKA. The incidence of urinary tract infection is very high among diabetic patients as compared with non-diabetic population. ${ }^{3}$ Impaired immune system and cystopathy are said to be the reasons for increased incidence of UTI in diabetic patients. ${ }^{4}$ The most common organisms implicated in urosepsis worldwide are gram negative bacilli, such as E. coli and Klebsiella. ${ }^{5}$

This study aims to determine the incidence of urosepsis in patients diagnosed with diabetic ketoacidosis who are admitted in the intensive care unit in Government Vellore Medical College Hospital. It also aims to determine the causative organisms and its antibiotic susceptibility.

Financial or Other, Competing Interest: None.

Submission 19-08-2016, Peer Review 31-08-2016,

Acceptance 03-09-2016, Published 12-09-2016.

Corresponding Author:

Anbarasu Duraisamy,

No. 34/E, Vellore, Main Road,

Arcot, Vellore District-632503,

Tamilnadu.

E-mail: dr.anbarasu.md@gmail.com

DOI: $10.14260 /$ jemds/2016/1218

\section{METHODOLOGY}

Patients with diabetes mellitus admitted in IMCU with Diabetic Ketoacidosis was included in the study. Those who denied to give consent, patients on prior antibiotics before admission and gestational diabetes mellitus were excluded from the study. A total of 103 patients were included in the study over a period of 6 months from March 2016 to August 2016. After obtaining informed and written consent, detailed clinical history was taken and physical examination was done and the findings were properly documented. Individuals who had been managed at some point with diet or an oral antidiabetic drug and with no prior history of DKA were classified as type 2 DM. Individuals whose medical records indicating continuous insulin treatment and prior diagnosis of type 1 DM were classified as type $1 \mathrm{DM}$. Capillary blood glucose was measured at admission and at required intervals. Urine sample was analysed for acetone and was sent for culture and antibiotic sensitivity. Blood sample was sent for culture and antibiotic sensitivity. Blood and urine culture samples were obtained before starting the patients on antibiotics. Patient's details regarding general information, physical examination and investigation results are entered in specially designed proforma.

\section{Statistical Analysis}

Statistical analysis was done by using SPSS 16 software. Quantitative data was expressed in mean, median, mode and standard deviation. Qualitative data was expressed by Chi square test. The difference was considered statistically significant when $P$ value $<0.05$. 


\section{OPERATIONAL GUIDELINES/DEFINITIONS USED}

\section{Diabetic Ketoacidosis}

Capillary blood glucose $>250 \mathrm{mg} / \mathrm{dL}$, and

Urine sample positive for acetone.

\section{SEPSIS}

Criteria I: Proof of bacteraemia or clinical suspicion of sepsis. Criteria II: Systemic Inflammatory Response Syndrome (SIRS). 6

\section{Two or More of the following Condition}

a. Fever (Oral temperature more than $38^{\circ}$ C) or hypothermia $\left(<36^{\circ} \mathrm{C}\right)$.

b. Tachypnoea ( $>24$ breaths $/ \mathrm{min})$.

c. Tachycardia (Heart rate $>90 / \mathrm{min}$ ).

d. Leucocytosis (WBC $>12000 / \mu \mathrm{L})$ or leucopenia $(\mathrm{WBC}<$ $4000 / \mu \mathrm{L})$.

Sepsis: Criteria I $+\geq 2$ criteria II. 7

\section{Urosepsis}

Sepsis caused by infection of the urinary tract.

\section{RESULTS AND ANALYSIS}

During the 6 months period, a total of 103 patients were admitted with diabetic ketoacidosis. Of the 103 patients, 40 (38.83\%) were males and $63(61.1 \%)$ were females.

Of the study population, $12(11.6 \%)$ were type $1 \mathrm{DM}$ and $91(88.4 \%)$ were type $2 \mathrm{DM}$. The mean age of the patients was $21+4.6$ years for type $1 \mathrm{DM}$ and $43+15.4$ years for type 2 DM.

5 patients $(4.85 \%)$ presented with DKA without prior history of diabetes mellitus.

Among the study population, 36 patients (34.9\%) had features of SIRS.

The precipitating features seen were poor drug compliance in 30 patients (29.1\%), newly diagnosed diabetes in 5 patients $(4.85 \%) ; 14$ patients $(13.59 \%)$ had urosepsis of which $11(78.57 \%)$ were females and $3(21.42 \%)$ were males $(\mathrm{p}<0.05)$. Of these 14 patients with urosepsis, 1 (7.14\%) was type $1 \mathrm{DM}$ and 13 (92.85\%) were type $2 \mathrm{DM}$ and this difference is statistically significant $(\mathrm{p}<0.05)$. This shows that urosepsis is a common precipitating factor for DKA in type 2 DM than type 1 DM $(\mathrm{p}<0.05)$.

6 patients expired and the mortality percentage is $5.8 \%$. All these fatal cases were type $2 \mathrm{DM}$.

Among the 14 patients with urosepsis, E. coli was grown in 9 patients (64.28\%), Klebsiella in 2 patients (14.28\%) and pseudomonas aeruginosa in 1 patient (7.14\%), staphylococcus epidermidis in 1 patient (7.14\%) and candida glabrata in 1 patient (7.14\%). The gender wise distribution of the organisms causing urosepsis in DKA is shown in table 1.

\begin{tabular}{|c|c|c|}
\hline $\begin{array}{c}\text { Organism } \\
\text { Grown }\end{array}$ & $\begin{array}{c}\text { No. of } \\
\text { Males (\%) }\end{array}$ & $\begin{array}{c}\text { No. of } \\
\text { Females (\%) }\end{array}$ \\
\hline E. coli & 2 & 7 \\
\hline Klebsiella pneumoniae & 1 & 1 \\
\hline $\begin{array}{c}\text { Pseudomonas } \\
\text { aeruginosa }\end{array}$ & 0 & 1 \\
\hline $\begin{array}{c}\text { Staphylococcus } \\
\text { epidermidis }\end{array}$ & 0 & 1 \\
\hline Candida glabrata & 0 & 1 \\
\hline \multicolumn{3}{|c|}{ Table 1: Distribution of Organisms causing Urosepsis } \\
\hline
\end{tabular}

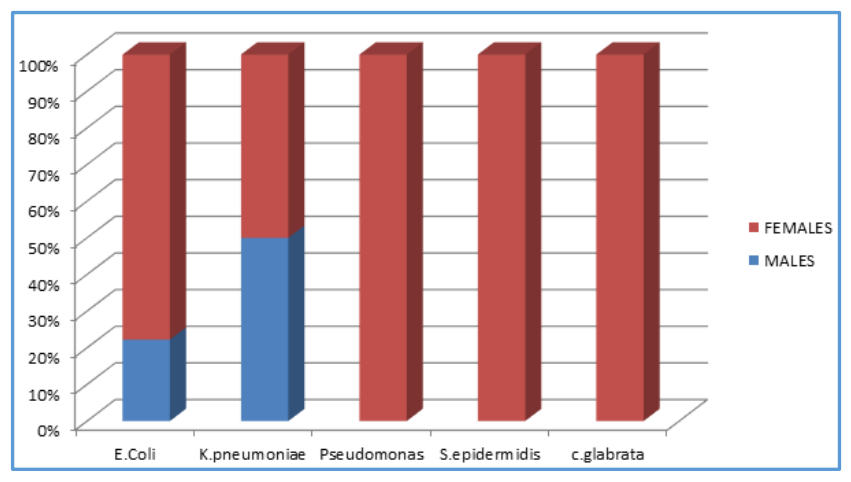

Gender wise distribution of organisms causing urosepsis in DKA.

The antibiotic resistance pattern for the isolated organisms were as follows:

\begin{tabular}{|c|c|}
\hline $\begin{array}{c}\text { Organism } \\
\text { Isolated }\end{array}$ & Resistance Pattern \\
\hline E. coli & $\begin{array}{c}\text { Cotrimoxazole (58\%), amikacin (9\%), } \\
\text { ofloxacin (44\%), amoxicillin clavulanic } \\
\text { acid (36\%), cefotaxime (47\%), } \\
\text { ciprofloxacin (47\%), nitrofurantoin } \\
(6 \%), \text { imipenem (5\%), cephalothin } \\
(36 \%) \text {, ceftazidime (27\%). }\end{array}$ \\
\hline $\begin{array}{c}\text { Klebsiella } \\
\text { pneumonia }\end{array}$ & $\begin{array}{c}\text { Cotrimoxazole (50\%), nitrofurantoin } \\
(50 \%), \text { ciprofloxacin, ceftriaxone, } \\
\text { cefotaxime. }\end{array}$ \\
\hline $\begin{array}{c}\text { Pseudomonas } \\
\text { aeruginosa }\end{array}$ & $\begin{array}{c}\text { Cotrimoxazole, ciprofloxacin, cefotaxime, } \\
\text { ampicillin-sulbactam, ceftriaxone. }\end{array}$ \\
\hline $\begin{array}{c}\text { Staphylococcus } \\
\text { epidermidis }\end{array}$ & $\begin{array}{c}\text { Clindamycin, erythromycin, } \\
\text { cotrimoxazole, ampicillin. }\end{array}$ \\
\hline \multicolumn{2}{|c|}{ Table 2 } \\
\hline
\end{tabular}

\section{DISCUSSION}

Diabetic ketoacidosis is one of the common emergencies of diabetes mellitus. In our study, the mean age of patients was $21+4.6$ years for type $1 \mathrm{DM}$ and $43+15.4$ years for type $2 \mathrm{DM}$. Of the study population, 36 patients (34.9\%) presented with features of SIRS. DKA as the presentation of Diabetes, which is known as DKA onset. Diabetes is seen in 5 patients (4.85\%). ${ }^{8}$ As per literature, the common precipitating factors for DKA are infection, poor drug compliance, newly diagnosed diabetes mellitus without any obvious precipitating factor. ${ }^{9}$ Respiratory and urinary tract infection are the common infections precipitating DKA. ${ }^{9}$ In our study, the incidence of urosepsis in DKA was $13.59 \%$. E. coli followed by Klebsiella pneumonia and pseudomonas aeruginosa were the organisms causing urosepsis in our patients. This observation is similar to the previous studies done by Srinivas et al, Chin-Hsun Chu et al and Acharya et al.9,10,11,12 The antibiotic resistance pattern of the isolated organisms is shown in the table (Table 1). E. coli which is the most common organism causing urosepsis is resistant to antibiotics such as cotrimoxazole, ofloxacin, cefotaxime, ciprofloxacin and sensitive to amikacin and nitrofurantoin. This observation is similar to the observations in the study done by Acharya et al. 12

The incidence of urosepsis is significantly higher in people with type $2 \mathrm{DM}$ than type $1 \mathrm{DM}$. This observation suggests that patients with type 2 DM transiently develop insulin deficiency during periods of stress (infection) and 
recover when the insult is subsided. On the contrary, people with type $1 \mathrm{DM}$ easily worsen to DKA on omission of medication. The other common precipitating factor is respiratory infection, which is not studied in our study.

The fatality rate of DKA was $5.8 \%$ in our hospital and all these fatalities were patients with type $2 \mathrm{DM}$.

\section{CONCLUSION}

In conclusion, our study exposes the fact that urosepsis is one of the common precipitating factors of DKA in patients with $\mathrm{E}$. coli being the commonest organism.

\section{REFERENCES}

1. Kasper, Fauci, Hauser, et al. Harrison's principles of internal medicine. 19th ed. Chapter 417, McGraw Hill 2015:2.

2. Gosmanov AR, Gosmanova EO, Cannon ED, et al. Management of adult diabetic ketoacidosis. Diabetes matab syndr obes 2014;7:255-64.

3. Patterson JE, Andriole VT. Bacterial urinary tract infections in diabetes. Infectious Disease Clinics of North America 1997;11(3):735-50.

4. Sridhar CB, Anjana S, Mathew JT. Acute infections. Chap 34. In: Ahuja MMS, Tripathy BB, Moses SGP, et al. eds. RSSD Itext book of diabetes mellitus. Hyderabad, India: 2002:471-8.
5. Sewify M, Nair S, Warsame S, et al. Prevalence of urinary tract infection and antimicrobial susceptibility among diabetic patients with controlled and uncontrolled glycemia in Kuwait. Journal Diabetes Research, Article ID 6573215, 2016;2016(2016):1-7.

6. http://www.uptodate.com/contents/sepsis-syndromesin-adults-epidemiology-definitions-clinical-presentationdiagnosis-and-prognosis.

7. Wagenlehner FME, Pilatz A, Naber KG, et al. Therapeutic challenges of urosepsis. European Journal Clinical Investigations 2008;38(Suppl 2):45-9.

8. Aizawa T, Katakura M, Taguchi N, et al. Ketoacidosis-onset noninsulin dependent diabetes in Japanese subjects. Am J Med Sci 1995;310(5):198-201.

9. Chih-Hsun C, Jenn-Kuen L, Hing-Chung L, et al. The occurrence of diabetic ketoacidosis in type 2 diabetic adults. www.tsim.org.tw/journal/jour10-6/P10_230.PDF. [accessed 29 Aug 2013].

10. Aswani SM, Chandrashekar U, Shivashankara $K$, et al. Clinical profile of urinary tract infections in diabetics and non-diabetics. Australas Med J 2014;7(1):29-34.

11. Lye WC, Chan RK, Kumarasinghe G, et al. Urinary tract infection in patients with diabetes mellitus. J Infect 1992;24(2):169-74.

12. Acharya D, Bogati B, Shrestha GT, et al. Diabetes mellitus and urinary tract infection. JMMIHS 2015;1(4):24-8. 